think that's a false dichotomy." She quotes, but seems far less at home with, Sarah Hrdy's flat statement: "I did not come into science and primatology because of a love for nonhuman primates. I was first attracted to problems and to things I wanted to understand ... There is really no one way of doing science ... we need people to stress theory as much as observation." One of Jahme's subjects, reading the section about herself, murmured: "Oh dear. This is half right and all wrong." To me that sums up the book, including some amazing scientific slip-ups.

A chapter I did like treats apes in the media. Jiggs, the chimp that played Cheeta in the Tarzan films, actually loathed women, including "Jane", whom he apparently cosies up to on the book's cover. (The dislike was mutual.) More telling is an incident when three television crews simultaneously followed Birute Galdikas through the forest, filming over each others' shoulders. The Japanese director insisted that Galdikas share a cup of sugary tea with a rehabitant orang-utan. Jahme and her own crew winced, knowing how their British audience idealizes "apes in the wild". Galdikas humoured the Japanese. Her priority was to do whatever she could to influence a country whose loggers were felling Bornean rainforest. People are willing to sell their image when it gives the research and the animals themselves more chance of survival.

That same dilemma appears in detail in Goodall's letters, with the nuances that inevitably escape Jahme's summary. You can read Africa in my Blood as a key document in the relation of human and animal, and of science and the demands of fame. Alternatively, just read it for fun.

Alison Jolly is in the Department of Ecology and Evolutionary Biology, Princeton University, Princeton, New Jersey 08544-1003, USA.

•.....................

\section{The spice of life}

The Variety of Life: A Survey and a Celebration of All the Creatures That Have Ever Lived

by Colin Tudge

Oxford University Press: 2000. 684 pp.

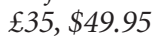

\section{Pat Willmer}

There is never a good time to write a book, especially one that addresses issues currently exercising the ingenuity and the advancing technology of biologists. This volume sets out to give us an overview of all living organisms and how they are related, and then doubles the difficulty of the task by including all the known extinct life-forms as well. At the turn of a century that has seen this field become the focus of an acceler- ating input from new methodologies, this is heroism. Since the author took 10 years over the job, he must have been daunted by how much the ground changed beneath his feet as he progressed. When the world around you is bursting with new kinds of information that are just beginning to shed fresh light on a key question, it is a brave man who decides to write about the answer! So why has Colin Tudge done it?

Tudge's answer is twofold: to help put taxonomy back at the centre of biology (and biodiversity) teaching, and to point out that nature is wonderfully varied. He aims to help professionals knowledgeable about one kingdom to find out about the others, and to help amateurs find their way around all the kingdoms (especially the animal kingdom, and it would help - as always - if they are particularly keen on vertebrates!).

The first four chapters do a great job of acquainting non-biologists with the nature and history of taxonomy and the impacts of cladistic and molecular analyses; they should be widely read (although many will dispute Tudge's emphases). Thereafter, however, non-biologists may find themselves overwhelmed by detail.

Professionals will probably pass over these first chapters and go for the detail, and they probably will go for it — in a field such
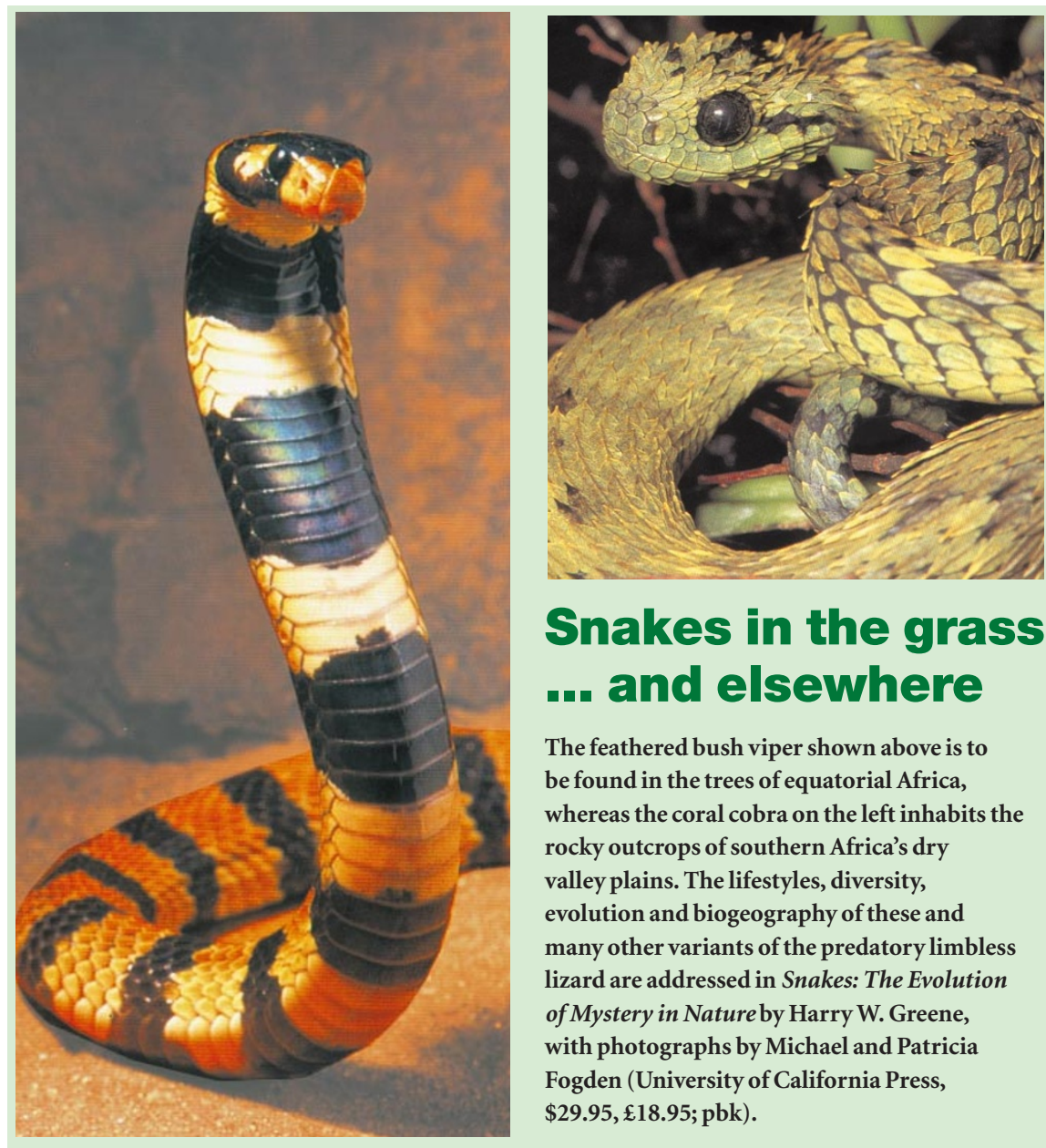

\section{Snakes in the grass and elsewhere}

The feathered bush viper shown above is to be found in the trees of equatorial Africa, whereas the coral cobra on the left inhabits the rocky outcrops of southern Africa's dry valley plains. The lifestyles, diversity, evolution and biogeography of these and many other variants of the predatory limbless lizard are addressed in Snakes: The Evolution of Mystery in Nature by Harry W. Greene, with photographs by Michael and Patricia Fogden (University of California Press, $\$ 29.95, \mathfrak{E} 18.95$; pbk). 
compete better in a difficult market-place. It deserves success for its heroic ambition. Pat Willmer is in the Bute Building, School of Biology, University of St Andrews, St Andrews KY16 9TS, UK.

\section{Tangled strands in the double helix}

\section{It Ain't Necessarily So: The Dream of the Human Genome and Other Confusions \\ by Richard Lewontin \\ New York Review of Books/Granta: 2000. \\ 330 pp. \$24.95/£14.99

The Triple Helix: Gene, Organism,
and Environment
by Richard Lewontin
Harvard University Press: 2000. 144 pp.
$\$ 22.95, £ 14.50$
Mark Ridley

Richard Lewontin is well known for his many positive contributions to evolutionary genetics, particularly the use of gel electrophoresis to measure genetic variation. He is also well known for his negative criticisms of certain genetic (or apparently genetic) ideas about humans, and of the 'reductionist' biological thinking that he believes underlies those ideas.

These two books are mainly in the second, critical mode. It Ain't Necessarily So is a collection of nine pieces from The New York Review of Books, together with short updating epilogues; they are mainly about humans. The Triple Helix is more abstract. It is based on three lectures that were published in Italian in 1998; Lewontin has added a fourth chapter on "New directions in biology" for the English edition. The Triple Helix is written more for biologists, although it assumes little technical knowledge: it is the material, rather than the level of treatment, that will (I suspect) mainly confine it to biological readers.

The Triple Helix looks at two big biological questions: development and adaptation. On development, Lewontin takes as text Sydney Brenner's remark that, if he had the complete sequence of DNA of an organism and a large enough computer, he could compute the organism. Lewontin describes this as "bad biology", because of the influence of the environment and random factors in development. On adaptation, he criticizes the idea that the external environment poses problems to which the organisms evolve solutions. This, too, is "bad biology" because the organism influences its environment too, through behavioural choices as well as by actively modifying it. He suggests that a better metaphor would be to say that the organism constructs its environment. $\mathrm{He}$

\section{A case of beetlephilia}

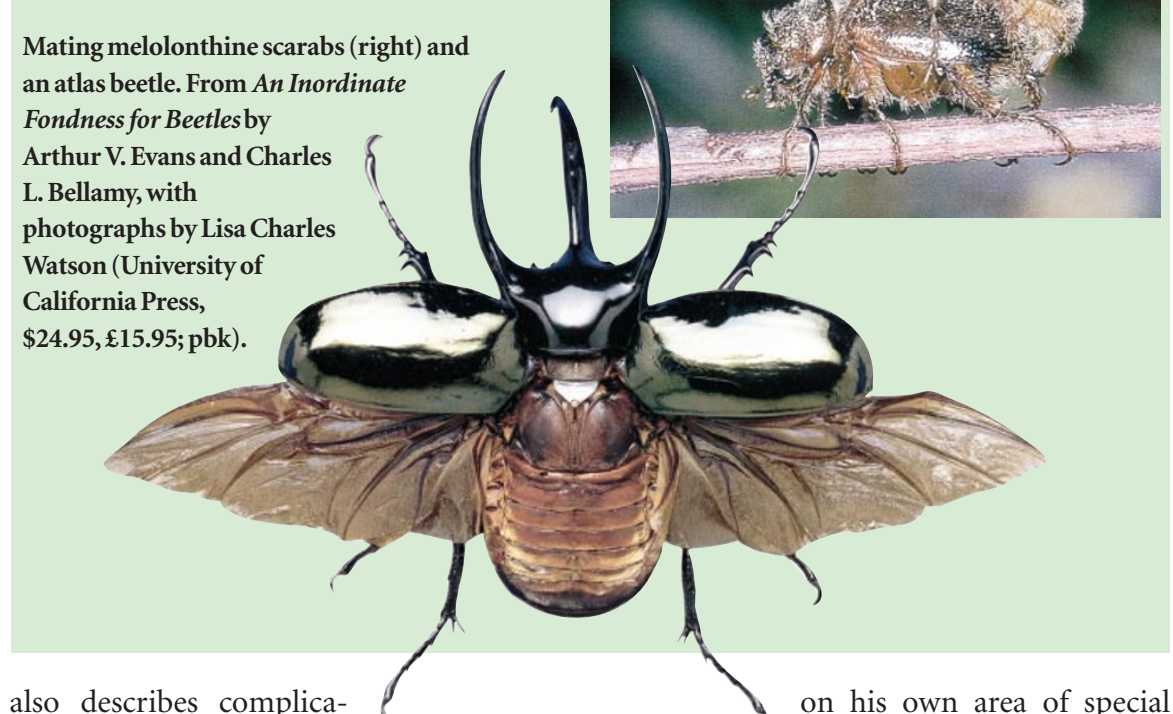
also describes complications caused by limited genetic variation, multiple peaks (one or two horns on a rhino) and epistatic fitnesses (in the Australian grasshopper Moraba).

These points, as Lewontin says, are well known to biologists. "But this in-principle knowledge cannot become folded into the structure of biological explanation unless it can be incorporated into the actual work of biologists," he adds.

This is the point at which the real controversy begins. In the case of adaptation, biologists have made more progress than Lewontin recognizes. Organisms do indeed influence, and in a sense partially construct, their environments. But methods exist to understand the situation, at least for frequency-dependent selection. In social behaviour, the fitness of an organism depends on what other organisms are doing; each organism's behaviour influences its social environment. The sex ratio is another (non-behavioural) well-analysed case. The organisms and their social environment "coevolve", as Lewontin says.

But what he does not say is that game theory allows us to model what will happen. Lewontin takes a negative view of what he calls "the metaphor of adaptation", saying that it "is now an impediment to a real understanding of the evolutionary process and needs to be replaced". But there are strands, such as game theory, within existing research that should contribute to the constructionist research programme he foresees.

Even for readers who do not agree with Lewontin, there is much of value in both books. He is superb at conceptually characterizing large research programmes in biology, and putting them in their historical context. In the penultimate paragraph of The Triple Helix, for instance, he comments on his own area of special expertise. "Before the mid1960s, experimental evolutionary genetics included a wide diversity of questions," he says, going on to list them. One of these questions was answered by gel electrophoresis. "The result was an abandonment of the research in almost all aspects of evolutionary genetics other than the characterization of genetic diversity. A single, easily acquired technique changed and pauperized, temporarily it is to be hoped, an entire field of study."

His writing is consistently elegant and readable, frequently funny, and abounding with provocative remarks. He can be a ferocious polemicist, and an effective (if sometimes slippery) debater — I'd trust him always to say something interesting, but not always to be fair to an opponent. One of his pet hates seems to be a remark made by Richard Dawkins [in The Selfish Gene] that the genes have "created us, body and mind". New York Review readers should have got the point, because Lewontin quotes it in four of the nine reprinted reviews. What he does not tell them is that the word "created" has an evolutionary, not a developmental, sense and does not illustrate the "genetic determinism" (or, more accurately, genetic fatalism) that Lewontin is mainly concerned to criticize.

The publisher George Weidenfeld once received a phone call from Thomas Wilson, head of Harvard University Press, saying, "I've got something important for you. Please don't ask any questions, just come over." "Next morning," Weidenfeld says, "I flew to Boston and called on Wilson. He closed the door and said in an emphatic stage whisper: 'the syndics of Harvard Press have seen fit to reject a manuscript of epochal importance." It was The Double Helix. J. D. Watson ("the great panjandrum of DNA") predictably gets the sharp end of Lewontin's 